\title{
ВИВЧЕННЯ ПРОБЛЕМИ САМОПРЕЗЕНТАЦІЇ ТА МОТИВАЦІї ЇЇ ПРОЯВУ В ДІТЕЙ 9-10 РОКІВ
}

УДК: 159.923.2:316.62

\section{Капустюк О. M.}

Кандидат психологічних наук, старший науковий співробітник лабораторії психології навчання імені

I. О. Синиці Інституту психології імені

Г. С. Костюка НАПН України, м. Київ (Україна)

\section{Пастушенко В. С.}

Науковий співробітник лабораторії психологї навчання імені I. О. Синииі Інституту психологї̈ імені Г. С. Костюка НАПН України, м. Київ (Украӥна)

\begin{abstract}
Анотація. $\quad$ - статті узагальнені результати вітчизняних та зарубіжних досліджень самопрезентаџійного феномена і мотивації його прояву у перехідний період від молодшого шкільного до підліткового віку. Виділено дві групи показників функціонування презентаційного феномена в дитячому віщі: когнітивні $і$ поведінкові. Підтверджено формування розуміння $i$ сприйняття молодшими школярами тактик самопрезентації: інтенсивний розвиток системи когнітивних репрезентацій, актуалізація самопрезентаційної мотивації, ї̈ реалізація на поведінковому рівні. Підібрано комплекс методик, щзо дозволяють простежувати особливості самопрезентації в умовах діяльнісної самореалізації в освітньому просторі.
\end{abstract}

Ключові слова: самопрезентація, сочіальний розвиток, публічне Я, презентаційна мотиваџія, стилі особистісного самовияву.

Постановка проблеми. Самопрезентація, крім комунікативної спрямованості, сприяє також більш повному усвідомленню дитини уявлень щодо самої себе, тому що, за визначенням Л.С. Виготського, саме знаково- символічне опосередкування дозволяє перевести у внутрішній план, тобто зробити усвідомленим особистістю значущий досвід.

Взаємодіючи 3 оточуючими, дитина розширює коло уявлень про себе і набуває 
здатності до їх демонстрації, спочатку, на елементарному неусвідомлюваному рівні, а 3 віком, на основі соціально і культурно прийнятих способів поведінки, це вербальна і невербальна демонстрація власної особистості в системі зовнішніх комунікацій.

Отже, як і у будь-якому середовищі, у дитячому шкільному $є$ субкультурні норми самопрезентації, завдяки яким дитина ідентифікує представників своєї групи, напрямки. Спосіб самопрезентації стає ритуальною поведінкою зі своєю символікою як спосіб розрізнення «своїх» $\mathrm{i}$ «чужих».

У сучасній науковій літературі $є$ ряд робіт, присвячених аналізу форм, стратегій i тактики самопрезентації (Е. Гофман, М. Снайдер, М.Р. Лірі, Р.А. Вікланд, Е. Джонес, Т.С. Піттман, Б . Шленкер, Р. Бауместер, С.Л. Доценко, I. С. Кон, Д. Майерс та ін.), однак майже відсутні дослідження особливостей самопрезентації дітей молодшого шкільного віку, а важливі психологічні висновки, подані у зарубіжних дослідженнях, сформульовані на підставі аналізу інформації на невеликих вибірках. $\mathrm{У}$ той же час дана проблема є гостро актуальною в зв'язку зі зростаючою потребою пошуку причин і механізмів труднощів організації міжособистісної взаємодії в дитячому колективі та соціальної дезадаптації дітей і підлітків.

Метою нашої статті є проаналізувати функціонування самопрезентаційного феномена та дослідити мотивацію його прояву в перехідний період від молодшого шкільного до підліткового віку в умовах діяльнісної самореалізації в освітньому просторі.

Перші повідомлення про формування «публічного Я» у дитячому віці з'явилися при аналізі суміжних проблем: вивченні закономірностей формування дитячої дружби, аналізі функцій груп однолітків; вивченні явища дезадаптації в дитячому віці; аналізі особливостей когнітивного розвитку дітей; вивченні вікових аспектів самомоніторингу; аналізі формування особистісних структур в дитячому віці, розвитку самосвідомості та Я- концепції дитини.

Аналізуючи питання розвитку особистісних стосунків між дітьми, Gottman та Mettetal [3] висунули гіпотезу про поетапне формування дружби. Їх триступенева модель передбачала поступове розгортання процесів міжособистісної взаємодії та соціальної перцепції. Серед основних механізмів другого етапу формування дружніх стосунків, що припадає на перехідний період від молодшого шкільного до підліткового віку, автори виділяють самопрезентаційну стратегію. У поведінці дітей простежується прагнення створювати позитивне враження в однолітків, подавати себе у найвигіднішому світлі, враховувати позицію партнера та передбачати наслідки своєї поведінки. Автори стверджують, що збереження «публічного обличчя» та репутації $\epsilon$ важливим аспектом взаємодії у дитячому віці. Результати даного дослідження узгоджуються iз висновками, зробленими на основі більш 
ранніх спостережень (Г.С.Костюк, А.А.Реан, Я.Л.Коломинский, О.В.Киричук та робіт, виконаних у наступні роки J.Hatch, B.Darby, A.Newcomb).

До 9-10-річного віку дитина остаточно розстається з роллю малюка, вона виросла й подорослішала. Це перехідний період від молодшого шкільного до підліткового віку, коли активно формується особистість, і стрімко відбуваються фізіологічні зміни в організмі.

Підлітковий вік - це, з одного боку, вік індивідуалізації, відкриття та ствердження свого унікального і неповторного «Я», а 3 іншого - вік соціалізації, вростання в світ людської культури і суспільних цінностей. І обидві ці лінії розвитку реалізуються на тлі загальної особистісної нестабільності [5].

Взаємодіючи 3 оточуючими, дитина розширює коло уявлень про себе і набуває здатності до їх демонстрації, спочатку, на елементарному неусвідомлюваному рівні, а 3 віком, на основі соціально і культурно прийнятих способів поведінки. Комплекс способів і стратегій представлення себе оточуючим позначається як самопрезентація (Ф. Артур, 2003). Це вербальна і невербальна демонстрація власної особистості в системі зовнішніх комунікацій. (В.С. Агєєв, 1987).

У вузькому значенні, самопрезентація це акт самовираження і поведінки людини, спрямований на те, щоб створити сприятливе враження про себе у Іншого як носія позитивного «Я». Самопрезентація в цьому випадку розглядається як вміння дитини подати себе у новому для неї становищі, в нових умовах перебування, в новому оточенні. Слова «сам», «саме» вживаються для надання особливої важливості особистій діяльності. Ми розглядаємо самопрезентацію як один 3 важливих аспектів соціальної адаптації дитини. Поряд 3 розвитком здатності іï до адаптації посилюється і прагнення до самопрезентації, самоствердження, тобто до різних стратегій «Я».

Незалежно від характеру процесу (стихійний чи регульований), самопрезентація формує у дитини 9-10 років певний рівень очікувань, стиль взаємостосунків, а також є засобом впливу на оточуючих. Самопрезентація передбачає наслідування дитиною культурних зразків поведінки як найбільш адекватним варіантам реагування на ті чи інші обставини спілкування.

При самопрезентації важливе значення мають соціальні очікування, пов'язані з образом «Я» і образом важливого «нншого».

У той же час, вирішуючи завдання самопрезентації, дитина у перехідний період виробляє стереотипи поведінки, які впливають на стиль самопрезентації. Обраний стиль $є$ неусвідомленим відображенням цінностей і самоставлення.

Отже, як і у будь-якому середовищі, у дитячому шкільному $є$ субкультурні норми самопрезентації, завдяки яким дитина ідентифікує представників своєї групи, напрямки. Спосіб самопрезентації стає ритуальним пове- 
дінкою зі своєю символікою як спосіб розрізнення «своїх» $\mathrm{i}$ «чужих».

У структурі досвіду самопрезентації можна виділити кілька компонентів: суб'єктивний, змістовний операційний та об'єктивний.

Суб'єктивний, або ціннісно-смисловий (образ «Я» і образ «Іншого», самоставлення, позиція, самооцінка) - яким чином дитина суб'єктивно відображає себе та інших людей (перцепція); задає контекст самопрезентації i буває конструктивним і неконструктивним.

Однією $з$ першооснов даного процесу виступає соціальне порівняння. M.Brewer, J.Weber, E.Pomerantz. Саме в період 9-10 років у дітей сформовується здатність порівнювати свої якості з відповідними характеристиками однолітків. Розвиток соціального порівняння веде до формування механізмів соціального та публічного Я.

Тут також мають значення особистісні мотиви. Дитина включається у будь-яку справу, якою зайнятий ровесник, заради того, щоб порівняти свої і його можливості. В ролі мотивів виступають порівняльні, аналогічні якості - свої і однолітка, можливості (вміння, знання, моральні якості), потреби (бажання, схильності). Перший варіант особистісного мотиву, коли вона прямо висловлює потреби у спілкуванні з ровесником, а не підпорядкований іншим потребам. Другий варіант особистісного мотиву - ровесник як цінитель тих якостей, які дитина вже виділила у собі як перевагу. Дитина демонструє свої вміння, знання і осо- бистісні якості, спонукаючи інших дітей підтверджувати їх цінності. Мотивом спілкування стають його власні якості відповідно властивості однолітка бути їх цінителем. Цей мотив також прямо пов'язаний з потребою в спілкуванні, з прагненням дитини пізнати свої можливості, підтвердити переваги, використовуючи відгук на них з боку ровесника [4, с.16].

Змістовний компонент - сукупність обставин, які оцінюються як значущі й незначущі.

Завдання самопрезентації вирішується дитиною часто спонтанно в незначних ситуаціях, в значущих ситуаціях характерне управління самопрезентацією, виходячи з умінь та індивідуальних особливостей дитини.

Операційний компонент - вміння, подання (знання), навички, способи дій, техніки, програми поведінки і т.п.

Однією з перших наукових робіт у цій сфері було дослідження, в якому аналізувалося розуміння дітьми 8-ми та 11-и років таких тактик самопрезентації як самопросування та привабливості (M.Bennet та C.Yeeles, 1990). Обидві ці тактики мають велику подібність, оскільки обидві включають позитивні установки стосовно свого Я і Я партнера, з одного боку вони, а з іншого - відрізняються складністю когнітивних операцій, що забезпечують їх розуміння. Дослідження присвячувалося перевірці гіпотези наявності відмінностей у розумінні дітьми даних тактик.

Зіставлення результатів молодшої i 
старшої групи реципієнтів показало значні зміни, що відбуваються у цьому процесі протягом молодшого шкільного віку. Діти молодшої підгрупи пояснюють самопрезентаційні ситуації, зосереджуючись на меті суб'єкта самопрезентації, не заглиблюючись в аналіз міжособистісного процесу. Вони не виділяють спроби суб'єкта презентації керувати враженнями партнера, впливати на соціальну оцінку. Як відзначають M.Bennet, C.Yeeles [6], лише 36 відсотків дітей 8-річного віку виявили здатність ідентифікувати міжособистісну природу ситуації.

Результати експерименту дали підставу P.Aloise-Young [1] зробити висновок про те, що до початку перехідного періоду від молодшого шкільного до підліткового віку відбувається інтенсивний розвиток самопрезентаційних умінь. Показником даного процесу $\epsilon$ підвищення рівня селективності у виборі особистісних характеристик відповідності до контексту ситуації. На початку вікового періоду діти не роблять відбору самопрезентаційної інформації, тоді як школярі старшої підгрупи демонструють уміння даного типу. У процесі самопрезентації школярі зосереджували увагу на ігрових уміннях, необхідних для взаємодії. Це свідчить про використання стратегії самопросування як найдоцільнішої за даних умов. Крім того, у даній підгрупі було зафіксовано підвищення рівня гнучкості самопрезентації за умови появи нової інформації стосовно аудиторії, що свідчить про розвиток моніторингу та вміння враховувати соціальні очікування партнерів 3 метою формування враження.

Заслуговує на увагу висновок про використання дітьми тактики самопросування шляхом повідомлення позитивної інформації про себе на фоні негативної про інших. Як показало дослідження, діти мають соціальні знання та вміння, необхідні для застосування цього типу поведінки.

Подібні результати були отримані під час дослідження усвідомлення дітьми самопрезентаційної тактики - хвастощі (M.Bennet, Yeeles, 1990) [6]. Результати обстеження дали підставу авторам стверджувати, що не існує відмінностей між дітьми 8-ми та 11-и років при позначенні даного типу поведінки, проте відмінності виникають при поясненні його мотиваційних основ: діти у перехідний період від молодшого шкільного до підліткового віку розуміють прагнення суб'єкта самопрезентації впливати на враження інших людей стосовно себе і дають пояснення у логіці міжособистісної взаємодії, тоді як діти молодшої вікової групи зосереджуються на внутрішньоособистісних детермінантах.

\section{Під об'єктивним компонентом ми розу-} міємо життєві обставини, в яких школяр перебуває в дитячому колективі, школі. Необхідність в самопрезентації виникає у випадках знайомства 3 цікавими людьми /друзями/, 3 новими людьми в компанії друзів, спілку- 
вання 3 вчителем, спілкування 3 однокласниками тощо.

Дослідниця Л. М. Мітіна включає самопрезентацію (в інтерпретації автора «самоподачу себе іншим») в опис основних функцій педагогічного спілкування поряд 3 інформаційною (обмін інформацією між учителем і учнями пізнавального й емоційнооцінного характеру); соціально-перцептивною (дає можливість педагогу і учням сприймати один одного, встановлювати той чи інший рівень взаєморозуміння і взаємоприйняття на основі залучення механізмів емпатії (співчуття, співпереживання)); інтерактивною (обмін образами, ідеями, діями, навичками, досвідом); афективною (емоційна стимуляція, «розрядка», полегшення, відчуття психологічного комфорту). На думку психолога, самопрезентація є значущою функцією і допомагає в самовираженні всім учасникам педагогічного процесу.

Публічні ситуації, у які одночасно включені і дорослі, і однолітки у молодших класах стимують самопрезентаційну поведінку, адресовану переважно вчителю як найбільш референтній фігурі. Його позитивні оцінки $є$ запорукою, отримати схвалення i прийняття у середовищі однолітків. У перехідний період від молодшого шкільного до підліткового віку відбувається поступове переорієнтування самоподачі на однолітків.

Для нашого дослідження особливий інтерес мали також роботи, у яких вивчався безпосередній вплив самопрезентаційної мотивації на навчання дітей. Навчальні ситуації включають у себе певні умови, які здатні підвищувати тривожність дитини стосовно того враження, яке вона справляє на навколишніх, наслідком чого є підвищення самопрезентаційної мотивації. Дослідження, проведені B.Hughens, H.Sulliva, J. Beaird, виявили, що в ситуації публічного оцінювання з боку вчителя яскраво простежується вплив самопрезентаційних мотивів на рівень домагань учнів. Цей процес має гендерні відмінності: дівчата знижують рівень домагань, хлопці, навпаки, віддають перевагу більш складним завданням. У ситуаціях, не пов'язаних 3 оцінюванням, подібних змін у рівнях домагань учнів не спостерігається. Ці результати пояснюються більшою потребою дівчаток у визнанні.

У цілому, аналіз наукової літератури у сфері дитячої самопрезентації показує, що у вивченні даного явища гендерний підхід використовується досить інтен-сивно. Стать $€$ одним 3 центральних компонентів Я концепції дитини, тому статево-рольова поведінка виступає важливим засобом формування позитивного враження про себе. Одним із соціальних факторів, що має потенційний вплив на статево-рольову поведінку визнається група однолітків. Дослідження доводять, що однолітки забезпечують підкріплення стереотипної презентації і виявляють різке несхвалення при їі порушенні Ре- 
зультати дослідження В. Fagot [6] свідчать, що дана тенденція започатковується ще у період дошкільного дитинства.

Позитивне підкріплення стереотипів є дієвим чинником самопрезентації: отримуючи схвалення за стереотипну поведінку діти, притримуються іiі довше, ніж ті, хто був покараний за контр-стереотипну. Вплив на самопрезентацію однолітків доведено також у дослідженні R.Banerjee, V.Lintern [2], де встановлено, що у присутності ровесників діти менш схильні гратися з іграшками, що трактуються оточуючими виключно як “дівчачі” чи “хлоп’ячі”. Важливим висновком про вплив однолітків на особистісні самовияви дітей $є$ результати дослідження P.Aloise-Young [1], які показують, що самопрезентаційна поведінка дитини біль-шою мірою знаходиться під впливом потенційно бажаних друзів, ніж під впливом реальної групи однолітків. Таким чином, самопрезентація перш за все мотивується бажанням увійти до певної групи, бути прийнятим нею.

Завершуючи обговорення питання аналізу проблеми дитячої самопрезентації у психологічній науці, можна зробити наступні висновки.

Дитяча самопрезентація розглядається як форма особистісного самовияву дитини, важливе соціальне уміння, розвиток якого $є$ необхідним аспектом формування Я-концепції дитини та їі взаємодії з іншими людьми.

Існуючі дослідження стосуються окре- мих аспектів самопрезентаційного феномена як у сфері мотивації, так і вибудовування бажаного образу.

Широко дискутується проблема мотиваційних джерел самопрезентації. Наукові підходи різняться: напрямом дії мотиву (спрямування на внутрішній світ - на соціальне середовище), відмінністю у визначенні змісту мотиву (акцентування психологічних чи соціально-психологічних аспектів).

У сфері мотивації дослідження зорієнтовані на спостереження зміни дитячого розуміння мотивів самопрезентації протягом молодшого шкільного віку. Було встановлено, що лінія розуміння іде від психологічних інтерпретацій до тлумачення у термінах міжособистісного процесу.

Таким чином, функціонування самопрезентаційного феномена у перехідний період від молодшого шкільного до підліткового віку характеризується наступними особливостями: самопрезентація переходить на усвідомлений рівень зумовлений потребою бути частиною групи, появою когнітивних умінь, прийняття ролі та координації перспективи двох і більше учасників соціальної взаємодії; функціонування самопрезентаційної стратегії характеризується вищим рівнем турботи про підтримання власного позитивного образу, ніж про підтримання образу партнера, прагнення заявити про себе як про самодостатньою індивідуальністю; у процесі навчальної діяльності самопрезентаційні покази перш за 
все адресовані вчителю; соціальний розвиток дітей більш підпорядкований прагненню отримати позитивну оцінку, ніж потребі у самопідтвердженні; поява концентрації на власній зовнішності; особистісна нестійкість, яка продиктована необхідністю відповідати психологічно-фізіологічним змінам, що відбуваються в організмі у даний період, а також змінам вимог, що пред'являються з боку соціуму.

Відповідно до логіки теоретичного аналізу функціонування самопрезентаційного феномена та дослідження мотивації його прояву в перехідний період від молодшого шкільного до підліткового віку в умовах діяльнісної самореалізації в освітньому просторі, здійснювався вибір методів емпіричного дослідження. В ході розробки програми даного дослідження було обрано 7 методик, що повинні будуть дозволити, на нашу думку, з'ясувати чи перебуває зміст і тип самопрезентації школяра у залежності від впливу чинників особистісного і ситуативного характеру (соціального статусу дитини у групі); чи постає однією із важливих детермінант змістових і процесуальних характеристиках самопрезентації статева належність; чи впливає шкільна мотивація на характер поведінкових особистісних самовиявів дітей, тобто на самопрезентацію та когнітивно-мотиваційні основи функціонування самопрезентаційної стратегії у перехідний період від молодшого шкільного до підліткового віку в умовах діяльнісної самореалізації в освітньому просторі.
Об'єктом нашого дослідження є особистість школяра у перехідний період від молодшого шкільного до підліткового віку у процесі міжособистісних взаємостосунків у колективі, а предметом дослідження - особливості самопрезентації школярів у перехідний період від молодшого шкільного до підліткового віку.

Експериментальною базою дослідження виступила базова спеціалізована школа № 49 м. Києва. В якості експериментальної групи був досліджений 4-А клас (30 чоловік), молодші школярі у віці 9-10 років.

Для нашого дослідження використовувалися наступні методики:

На першому етапі вивчалися особливості самопрезентації школярів (дві методики).

Перше завдання даного етапу спрямоване на виявлення кількісних і якісних показників когнітивного та емоційно-оцінного компонентів вербальної самопрезентації (самоописів) дошкільників 3 детальним аналізом представленості у висловленні таких компонентів: Я-фізичного, Я-психічного і Ясоціального, а також аналіз активного словника тематичної емоційно-оцінної лексики за кожним із виділених компонентів. Для цього школярам була запропонована методика самоопису за планом: 1) «Що я знаю про себе?» та 2) «Я у майбутньому».

Наступне завдання на самопрезентацію у невербальній формі - це проективна методика «Намалюй себе» (модифікований варіант методики А.А. Реана, 2004). Аналіз малюнків 
проводиться методом шкалювання за такими параметрами: представленість в малюнках основних компонентів тіла і характер їх зображення; кольори, використані в «автопортреті»; розташування «автопортрета» на аркуші, сюжет. Сума балів за результатами аналізу малюнка оцінюється за абсолютною величиною, що дозволить виявити три рівні здібності дитини до невербальної самопрезентації: високий рівень, позитивна самооцінка; високий рівень, негативна самооцінка; низький рівень здатності до самопрезентації, несформоване уявлення про фізичне «Я».

На другому етапі ми визначатимемо міжособистісний статус кожного школяра та виявлятимемо структуру взаємостосунків у класі. Дослідження проводитиметься за методикою діагностики міжособистісних стосунків та міжгрупових відносин (соціометрія) Дж. Морено. Дана методика передбачає вибір партнера для спільної акції шляхом відповіді на питання типу: «З ким би ти хотів?». Такі питання називаються критеріями вибору.

Для більшої достовірності даний етап дублювався 3 проміжком часу в півтора місяця.

На третьому етапі ми вивчатимемо мотиваційну сферу учнів засобами трьох методик. Методика «Чотири питання», розроблена та апробована Н. Я. Большуновою (2005). Методика $є$ дослідницькою. Перевірена на надійність і валідність.

Особливість методики полягає в тому, що її питання звернені до різних рівнів психіки і свідомості. Перше питання («Що Ви найбільше цінуєте в житті?») апелює до свідомості і самосвідомості людини, воно вимагає досить добре відрефлексованих і вербально позначених відповідей. Друге («Що Ви найбільше ненавидите в житті?») і третє («Чого Ви найбільше в житті боїтеся?») звернені до області переживань, почуттів, емоцій. Четверте питання («Якби Ви були чарівником, що б Ви зробили в першу чергу?») є проективним. Це дозволяє здійснити якісний аналіз внутрішньої узгодженості цінностей.

Для вивчення типу взаємозв'язків молодших школярів у класі використовується скорочена анкета В. Смекайли і М. Кучер «До якого типу взаємин ти схильний». До даної анкети ми доєднаємо ще три питання спрямованих на визначення провідних мотивів спілкування молодших школярів 3 однолітками.

Для визначення ставлення дітей до школи і навчального процесу, емоційного реагування на шкільну ситуацію використовується анкета Н. Г. Лусканової «Оцінка шкільної мотивації». Наявність у дитини мотиву добре виконувати всі пред'явлені школою вимоги і показати себе з найкращого боку, змушує учня проявляти активність у відборі і запам'ятовуванні необхідної інформації. При низькому рівні навчальної мотивації спостерігається зниження шкільної успішності. Учням мають відповісти на питання, обравши одну із запропонованих відповідей по кожному питанню. 
Напівпроективний тест Х. Д. Шмальта, що отримав назву МД-решітка (решітка мотивації досягнення).

МД-решітка розроблена для діагностики мотивів, що входять в структуру мотивації досягнення школярів у віці 9 - 11 років. Тест також дозволяє отримати дані щодо прояву мотивації досягнення у різних сферах діяльності. Автор виділяє найбільш значущі: навчання, спорт, музика, допомога, самоствердження, предметно-маніпулятивна діяльність.

Стимульний матеріал тесту складається iз 18-ти картинок-малюнків, кожний 3 яких супроводжує постійний список із 18 тверджень відповідної тематики.

Також для вивчення психологічних особливостей процесу самопрезентації учнів 9 -11 років ми включимо рівень навчальних досягнень за 4 клас (початковий, середній, достатній та високий), а також опис кожного учня та кожної учениці класним керівником.

На основі аналізу результатів наукових досліджень можна виділити дві групи показників функціонування презентаційного феномена у дитячому віці.

Що стосується поведінкових показників: зміна поведінки дитини у публічній ситуації; підвищення рівня самомоніторингу як специфічної форми саморегуляції (контроль за своєю поведінкою, керування власними експресивними виявами, спостереження за реакцією партнерів по взаємодії); застосування дітьми поведінкових тактик, які належать до групи презентаційних (акцентування позитивних рис та заперечення негативних, переорієнтація уваги партнера на інші аспекти ситуації, зміна позиції стосовно партнера).

Когнітивні показники: розуміння дітьми презентаційних та самопрезентаційних намірів; здатність до інтерпретації соціальної ситуації у термінах міжособистісного процесу; здатність до виокремлення ситуацій, що активізують презентаційну тенденцію; селективність у виборі поведінкової стратегії; передбачення результатів презентаційної поведінки, iї оцінки з боку партнерів по взаємодії; усвідомлення дітьми здатності впливати на висновки оточуючих через застосування певних презентаційних тактик.

\section{Перелік використаних джерел:}

1. Aloise-Young P. Peer influence on smoking initiation during early adolescence: a comparison of group members and group outsiders //Journal of Applied psychology.-1994. - Vol.79, № 2.-P.281-287.

2. Banerjee R., Lintern V. Boys will be boys: the effect of social evaluation concerns on gender-typing //Social Development.- 2000.-Vol.9, № 3.- P.398-408.

3. Vander-Zanden J., Human Development. New York: McGraw-Hill Inc., 1993.-715p

4.ДеревянкоР. И., Особенност и мот ивов общения со взрослым и сверстниками у дошкольников: Дис. кандидат психологических наук [Текст] . - М.: 1983 - 124c.

5. Дьякова Е. В. Постановка проблемы изучения особенностей самосознания и навыков самопрезентации у младших подростков с задержкой психического развития / Ученые записки Орловского государственного университета. - 2013г. - №5 (55), - С. 239-241. 
6. Корчакова Н. В. Психологічні особливост і особист існої самопрезентації в молодшому шкільному віці: дис... канд. психол. наук: 19.00.07 / Прикарпатський ун- т ім. Василя Стефаника. - Івано-Франківськ, 2004.

\section{References (Transliteration):}

1. Aloise-Young P. Peer influence on smoking initiation during early adolescence: a comparison of group members and group outsiders //Journal of Applied psychology.-1994. - Vol.79, \# 2.-P.281-287.

2. Banerjee R., Lintern V. Boys will be boys: the effect of social evaluation concerns on gender-typing //Social Development.- 2000.-Vol.9, \# 3.- P.398-408.

3. Vander-Zanden J. Human Development. New York: McGraw-Hill Inc.,1993.-715p

4. Derevyanko R.I. Osobennosti motivov obscheniya so vzroslyim i sverstnikami u doshkolnikov: Dis. kandidat psihologicheskih nauk [Tekst] / R. I. Derevyanko. - M.: $1983-124 \mathrm{~s}$.

5. Dyakova E.V. Postanovka problemI izucheniya osobennostey samosoznaniya i navIkov samoprezentatsii $u$ mladshih podrostkov s zaderzhkoy psihicheskogo razvitiya / Uchenyie zapiski Orlovskogo gosudarstvennogo universiteta. - 2013g. - \#5 (55), - S. 239-241.

6. Korchakova N. V. PsihologIchnI osoblivostI osobistIsnoYi samoprezentatsIYi v molodshomu shkIlnomu vItsI: dis... kand. psihol. nauk: 19.00.07 / Prikarpatskiy un- t Im. Vasilya Stefanika. - Ivano-FrankIvsk, 2004.

\section{Kapustyuk Elena}

Candidate of psychological sciences, senior researcher at I. O. Sinitsy Laboratory of pedagogical psychology of $G$. S. Kostyk Institute of Psychology of The National Academy of Pedagogical Sciences of Ukraine, Kyiv (Ukraine).

\section{Pastushenko Valentine}

Senior researcher at I. O. Sinitsy Laboratory of pedagogical psychology of G. S. Kostyk Institute of Psychology of The National Academy of Pedagogical Sciences of Ukraine, Kyiv (Ukraine).

\section{STUDY OF PROBLEM OF SELFDETERMI- NATION AND MOTIVES OF ITS EXPRES- SION BY 9-10 YEARS OLD CHILDREN}

The article investigates new enough phenomenon in psychological science - the phenomenon of self and motivation of its manifestation in the transition from primary school to adolescence. The relevance of studying this problem is growing because of the need to find causes and mechanisms of interpersonal interaction problems in the children's collective and social exclusion of children and adolescents.

Two groups are distinguished performance of the presentation of the phenomenon in children with cognitive and behavioral. By cognitive include: the ability to interpret social situations; selectivity in the choice of behavioral strategies; prediction results presentation behavior and its evaluation; awareness of children's ability to influence the opinions of others through the use of certain presentational tactics. As for the behavior, then - a change in the child's behavior in public situations; raising self-checking as a specific form of self-regulation; kids use behavioral tactics that belong to the group presentation.

The structure of self-experience it singled out the following components: subjective, objective and meaningful operational components.

As for the motives self-expressional behaviour, we are talking about personal motives (comparison of their features and the same age) motives communication, influence self- 
expressional motives to the level of harassment of students in a study of the situation pupil-teacher, personal self-presentation is motivated by the desire to enter into a particular group, to be accepted it.

Overall, a set of techniques that allow trace features in terms of self-fulfillment and activity in the educational space.

Keywords: self-presentation, social development, public I presentation motivation, personal expression styles.

\section{Капустюк Елена Николаевна}

Кандидат психологических наук, старший научный сотрудник лаборатории психологии обучения имени И.А. Синицы Института психологии имени Г.С.Костюка Национальной академии педагогических наук Украины, г. Киев (Украина).

\section{Пастушенко Валентина Семеновна}

Научный сотрудник лаборатории психологии обучения имени И.А. Синищы Института психологии имени Г.С.Костюка Национальной академии педагогических наук Украины, г. Киев (Украина).

\section{ИЗУЧЕНИЕ ПРОБЛЕМЫ САМОП- РЕЗИНТАЦИИ И МОТИВАЦИИ ЕЁ ПРО- ЯВЛЕНИЕЯ У ДЕТЕЙ 9-10 ЛЕТ}

Аннотация. В статье обобщены результаты отечественных и зарубежных исследований самопрезентацийного феномена и мотивации его проявления в переходный период от младшего школьного к подростковому возрасту. Выделено две группы показателей функционирования презентационного феномена в детском возрасте: когнитивные и поведенческие. Подтверждено формирование по- нимания и восприятия младшими школьниками тактик самопрезентации: интенсивное развитие системы когнитивных репрезентаций, актуализация са-мопрезентационной мотивации, ее реализация на поведенческом уровне. Подобрано комплекс методик, позволяющих прослеживать особенности самопрезентации в условиях деятельностной самореализации в образовательном пространстве.

Ключевые слова: самопрезентация, социальное развитие, публичное Я, презентационная мотивация, стили личностного самовыражения. 